\title{
The Economic Consequences of an Import Surcharge: Theory and Empirical Evidence for the U.S. Economy
}

\author{
Filip Abraham, Alan V. Deardorff, and Robert M. Stern, The \\ University of Michigan
}

This paper analyzes the impact of a 20 percent import surcharge on all U.S. imports and on imports from Japan, South Korea, Taiwan, and Brazil. The analytical framework is based upon the Michigan Model of World Production and Trade. We also discuss the methodology and results of two recent papers on the effects of an import surcharge. The empirical results indicate that, while the macroeconomic consequences of an import surcharge would be limited, significant intersectoral trade and employment adjustments would take place. The competitive position of U.S. tradable industries may improve or deteriorate depending on whether the dollar depreciates or appreciates in response to the import surcharge.

\section{INTRODUCTION}

In the first months of 1985 various legislative proposals for reducing the U.S. trade and budget deficits were set forth in the U.S. Congress. These proposals included a 20 percent surcharge on all imports or on imports from selected countries, especially those with large trade surpluses with the U.S. The ostensible purpose of the general surcharge was to increase government revenues while, at the same time, lowering imports. The selective measures were intended to curb import flows and thus to bring pressure to bear on the affected countries to open their markets to U.S. goods.

However, none of these measures was passed by Congress during 1985 , because of doubts about their effectiveness and also because they faced a certain veto by President Reagan. The subsequent sharp depreciation of the dollar, beginning in September 1985, temporarily relieved the trade concerns of Congress, and the import surcharge issue

Address correspondence to Professor Alan Deardorf, Department of Economics, University of Michigan, Ann Arbor, 411 Lorch Hall, Ann Arbor, MI 48109.

Received July 1986; final draft accepted November 1986. 
was pushed further into the background. But the persistence of the trade deficit in early 1986, coupled with heightened political awareness of trade as an issue for the 1986 elections, resulted in a renewal of Congressional enthusiasm for restrictive trade measures. Thus, on May 22, 1986 the House of Representatives passed a comprehensive trade bill containing a wide array of trade measures. Selective import restrictions were mentioned as one possible form of punishment for countries with "unfair" trade restrictions that affected U.S. interests adversely.

Although these various proposed measures have been discussed and debated in political circles and in the media, the measures have not been analyzed to any great extent by academic economists. The purpose of our paper, accordingly, is to undertake such an analysis in order to clarify some of the important conceptual issues and the magnitude of the effects involved. The framework for our analysis is based upon the Michigan Model of World Production and Trade. In our paper we focus in particular on the effects of general and selective import surcharges that might be imposed by the United States if the Congress succeeded in forcing the President's hand. Although the Michigan model is primarily suited for detailed sectoral analysis of various trade measures, it may also provide insight into some related macroeconomic questions. In carrying out our analysis, we shall have occasion to discuss the methodology and results of two recent papers on the effects of an import surcharge. Rousslang and Suomela (1985) use a partial equilibrium approach to analyze the sectoral trade adjustments to a U.S. import surcharge, while Klein, Pauly and Petersen (1985) carry out various surcharge simulations with the LINK econometric model and primarily emphasize the macroeconomic effects involved.

In Section 2 of our paper we present a theoretical framework based on the Michigan model for analyzing the surcharge and then describe the various policy experiments. Section 3 compares the Michigan model to Rousslang and Suomela's partial equilibrium approach. It is assumed here that trade flows determine the exchange rate. On this basis, we analyze the impact of a general 20 percent surcharge on all imports and, alternatively, the economic adjustments that might occur if there were a 20 percent selective surcharge on imports from Japan, South Korea, Taiwan, and Brazil. In a final section, we assume that a general 20 percent import surcharge on all goods leaves the exchange rate unchanged and relate the results of the Michigan and Project LINK models. 


\section{REPRESENTATION OF AN IMPORT SURCHARGE IN THE MICHIGAN MODEL}

The Michigan model, which is set out in detail in Deardorff and Stern (1986), captures detailed economic relations among 34 countries in 22 tradable and 7 nontradable goods industries. One of its basic characteristics is that producers and consumers of each country distinguish, within the tradable industries, between home goods, which are produced and consumed domestically, and those that are exported or imported. Different demand and supply functions therefore exist for home and export products. It is further assumed that demanders regard home-produced and imported goods as imperfect substitutes, but imports from various foreign countries as perfect substitutes. The latter is in contrast to some computational trade models in which imports are differentiated with respect to country of origin and bilateral export and import functions are defined (e.g., see Brown 1984).

The supply side of the model is based on profit maximization in each industry. Perfectly competitive exporters and producers for the domestic market combine labor, domestic and imported intermediate inputs, and a fixed amount of capital to produce an optimal amount of output. This leads to supply functions which depend on the product price and the cost of the various inputs:

$$
\begin{aligned}
& S_{i j}^{x}=S_{i j}^{x}\left(p_{i j}^{x}, p_{i l}^{h} \ldots p_{i n^{\prime}}^{h}, p_{i l}^{m} \ldots p_{i n}^{m}, w_{i j}, K_{i j}^{x}\right) \\
& \begin{array}{r}
j=1, \ldots, n i=1, \ldots, m \\
S_{i j}^{h}=S_{i j}^{h}\left(p_{i j}^{h}, p_{i l}^{h} \ldots p_{i n^{\prime}}^{h}, p_{i l}^{m} \ldots p_{i n}^{m}, w_{i j}, K_{i j}^{h}\right) \\
j=1 \ldots n^{\prime} \text { and } i=1 \ldots m
\end{array}
\end{aligned}
$$

where

$S_{i j}^{x}, S_{i j}^{h}=$ supply of good $j$ by country $i$, export and home sectors, respectively,

$p_{i j}^{x} \quad=$ domestic price of exports of good $j$ in country $i$,

$p_{i j}^{h} \quad=$ home-sector price of good $j$ in country $i$,

$p_{i j}^{m} \quad=$ domestic price of import $\operatorname{good} j$ in country $i$,

$K_{i j}^{x}, K_{i j}^{h}=$ (total) capital stock of industry $j$ in country $i$, export and home sectors, respectively,

$w_{i j} \quad=$ nominal wage rate in sector $j$ of country $i$,

$n \quad=$ number of tradable goods,

$n^{\prime}-n=$ number of nontraded goods,

$m=$ number of countries. 
Once the profit-maximizing level of output of an industry is determined, input demand functions are readily obtained.

Utility-maximizing consumers make a choice between imported and domestically produced consumption goods and base their decisions on relative prices and their level of income. Total demand for home and imported goods is found as the sum of final and intermediate demand and can be written as

$$
\begin{aligned}
& D_{i j}^{m}=D_{i j}^{m}\left(p_{i j}^{m}, p_{i j}^{h}, E_{i}, S_{i l}^{h} \cdots S_{i n^{\prime}}^{h}, S_{i l}^{x} \cdots S_{i n}^{x}\right), \\
& D_{i j}^{h}=D_{i j}^{m}\left(p_{i j}^{m}, p_{i j}^{h}, E_{i}, S_{i l}^{h} \cdots S_{i n^{\prime}}^{h}, S_{i l}^{x} \cdots S_{i n}^{x}\right),
\end{aligned}
$$

where

$$
\begin{aligned}
& D_{i j}^{m}=\text { demand of imports of good } \mathrm{j} \text { in country } \mathrm{i}, \\
& D_{i j}^{h}=\text { demand for products of home sector } \mathrm{j} \text { in country } \mathrm{i}, \\
& E_{i}=\text { aggregate expenditure in country } \mathrm{i} .
\end{aligned}
$$

Output levels appear in the demand functions because they determine the demand for intermediate inputs.

Equality between domestic supply and demand yields the equilibrium prices of home goods. The import and export prices of a good $j$ are related to the world price $p_{j}{ }^{w}$, which guarantees equilibrium between total world demand and supply. Exporters receive the domestic equivalent of the word price,'

$$
p_{i j}^{x}=R_{i} \mathrm{p}_{j}^{w},
$$

where

$$
\begin{aligned}
R_{\mathrm{i}}= & \text { exchange rate of country } i \text { (domestic currency } \\
& \text { per unit of numeraire currency). }
\end{aligned}
$$

Tariffs further increase the domestic prices of imported goods. Hence,

$$
p_{i j}^{m}=\mathrm{R}_{i}\left(1+\mathrm{t}_{i j}^{m}\right) \mathrm{p}_{j}^{w},
$$

where

$$
\mathbf{t}_{i j}^{m}=\text { ad valorem tariff on imports of good } j \text { into country } i .
$$

In a flexible exchange rate system, the exchange rate adjusts to maintain balance of payments equilibrium and can therefore be calculated from 


$$
\sum_{j=1}^{n} p_{\mathrm{j}}^{\mathrm{w}}\left(S_{\mathrm{ij}}^{\mathrm{x}}-D_{\mathrm{ij}}^{\mathrm{m}}\right)+B_{\mathrm{i}}^{\mathrm{ko}}=0
$$

where

$$
B_{i}^{k o}=\text { exogenous capital inflow in country } i \text {. }
$$

Equations (1) through (7) provide the basis for studying the effects of an import surcharge in the Michigan model. A 20 percent surcharge on all imports is represented by adding 20 percentage points to the current levels of all tariff rates. Similarly, we can analyze the effects of increasing tariff rates on U.S. imports from particular countries. These tariff measures raise the domestic prices of imported products in equation (6). Consumers will shift from imported to home goods and producers will buy more intermediate inputs from domestic suppliers. This higher demand for domestically produced goods pushes up their price, which reverses part of the initial decline in import demand. More expensive home goods also affect intermediate production costs, which were already increasing in response to higher import prices. Producers in the home goods sector are more than compensated for these increases by higher output prices and demand. However, prices of export goods are determined internationally and are not likely to adjust enough to maintain export profits at the same level. In fact, in all experiments in this paper, declining import demand in the country with the import surcharge (the U.S.) leads to lower world prices. Consequently, profits of export firms unambiguously fall in response to the surcharge. Therefore, export production declines, while the output of other firms expands, entailing a reallocation of labor from the export to the home goods sector.

In the Michigan model, the response of total production and employment to an import surcharge depends crucially on the macroeconomic assumption made about aggregate expenditure. Imposing tariffs and using tariff revenues to reduce the government budget deficit decreases aggregate expenditure and causes unemployment. Since few policymakers would be likely to advocate an import surcharge if a substantial number of jobs were to be lost, we assume in our experiments that aggregate expenditure adjusts to maintain the same overall employment level. One way to achieve such constant employment is by expansionary monetary or fiscal policy. Obviously, if expansionary fiscal policy is conducted, part of the tariff revenue is spent again so that the reduction in the budget deficit would be less than our results suggest. Furthermore, there are other effects of fiscal and monetary policies that may serve to limit declines in employment. For example, 
a reduced government budget deficit is likely to lower interest rates, limit international capital inflows, bring about a depreciation of the dollar, and stimulate investment in home and export production.

These links among the deficit, the rate of interest, and the exchange rate have often been cited by proponents of the import surcharge. They argue that a surcharge would correct the overvaluation of the dollar and thus restore the competiveness of U.S. producers. Yet it is hard to predict how the dollar will react to an import surcharge. For example, if this policy measure, by reducing import demand more than contracting export production, improved the trade balance, the dollar might well appreciate. In that case, analyzed in the first and second experiments below, a reduced budget deficit helps to stabilize aggregate employment, but the exchange rate is assumed to be determined by trade adjustments to the import surcharge. In their paper, Rousslang and Suomela make the same assumption about the exchange rate, which allows us to compare the methodology and results of their study and our own. Alternatively, in a third experiment, we assume that the dollar is fixed at its initial value, so that the import surcharge leaves the exchange rate unchanged. This scenario is considered in one of the Project LINK simulations, so that we are also able to compare the LINK and Michigan models in more detail below.

We assume throughout the paper that there is no retaliation of other countries against the U.S. import surcharge. One could argue that most European countries would welcome lower real interest rates and would therefore refrain from strong retaliatory action, while Japan would, at most, stop its limited efforts at opening its domestic markets to U.S. exports. On the other hand, in the presence of renewed protectionist sentiments all over the world, a U.S. import surcharge could easily trigger a costly trade war. In that event, all countries would suffer and, in ignoring this possibility, our results might be overly optimistic.

We now turn to the experiments where the exchange rate is determined by the balance-of-payments equilibrium. We first discuss Rousslang and Suomela's partial equilibrium approach to the import surcharge. Subsequently, the results of both studies are presented.

\section{AN IMPORT SURCHARGE WITH A TRADE- DETERMINED EXCHANGE RATE}

\section{A. The Partial Equilibrium Approach to an Import Surcharge}

Rousslang and Suomela seek to measure the impact of a U.S. import surcharge on the U.S. trade balance, exchange rate, and government 
revenues. They follow closely the methodology developed by Basevi (1968), who only models the foreign sector of the economy and does not distinguish between export and home-good production or between traded and nontraded goods. He postulates supply and demand functions for exports and imports, which are then solved for the equilibrium exchange rate. Export supply depends on the own export price and can be written as:

$$
S_{i j}^{x}=S_{i j}^{x}\left(\mathrm{p}_{i j}^{x}\right)
$$

Similarly, the domestic price of imports is the main determinant of import demand:

$$
D_{i j}^{m}=D_{i j}^{m}\left(p_{i j}^{m}\right)
$$

Foreign exporters supply more imports to the home market when the product price in foreign currency goes up. For simplicity, the foreign currency is taken as the world currency so that foreign suppliers of good $j$ receive the world price $p_{\mathrm{j}}{ }^{\mathrm{w}}$. In that case, the supply function of exports becomes

$$
S_{i j}^{n}=S_{i j}^{m}\left(p_{j}^{w}\right)
$$

where

$$
S_{i j}^{m}=\text { supply of imports of good } j \text { to country } i
$$

Foreign consumers buy more import goods when import prices in foreign markets go down. Since retaliation is not considered, foreign tariff changes can be ignored. Thus, demand for exports of country i responds directly to changes in the world price:

$$
D_{i j}^{x}=D_{i j}^{x}\left(p_{j}^{w}\right) \text {, }
$$

where

$D_{i j}^{x}=$ foreign demand for exports of sector $j$ in country $i$.

In equilibrium, import demand equals import supply and the same holds for exports. Recalling the definition of import and export prices in equations (5) and (6), the equilibrium quantities of exports $\left(X_{\mathrm{ij}}\right)$ and imports $\left(M_{\mathrm{ij}}\right)$ can be solved as a function of the exchange rate and the tariff structure:

$$
\begin{gathered}
X_{i j}=X_{i j}\left(R_{i}\right) \\
M_{i j}=M_{i j}\left(R_{\mathrm{i}}, t_{\mathrm{ij}}^{\mathrm{m}}\right)
\end{gathered}
$$

In a flexible exchange-rate system, the equilibrium exchange rate is derived from the equilibrium requirement for the balance of payments. 
The only remaining exogenous variables are the tariff rates. With the necessary estimates for import and export elasticities, ${ }^{2}$ the effects of an import surcharge on $M_{i j}, X_{i j}$, and $R_{i}$ can be calculated.

There are several important differences between Rousslang and Suomela's partial approach and the Michigan model's general equilibrium approach.

1. Since Rousslang and Soumela do not take into account the role of intermediate inputs in the production decisions of export firms, their specification in equation (1b) does not capture the intermediate cost effects of the import surcharge and their negative impact on export production.

2. The absence of intermediate inputs also affects Rousslang and Suomela's import demand equation (4b), since output levels do not appear as explanatory variables. Yet as a result of the import surcharge, fewer intermediate inputs are purchased abroad. Hence, Rousslang and Suomela's framework ignores one source of lower import demand. On the other hand, they make no distinction between home goods and imports. Rising prices of home goods thus do not offset part of the initial reduction in imports. For this reason, Rousslang and Suomela overestimate the negative impact of the surcharge on final import demand.

3. In the partial equilibrium approach, world prices are exogenously given to producers and consumers in each country. The absence of a world trade equilibrium rules out any indirect transmission of the import surcharge via changing world prices. In the experiments with the Michigan model, the U.S. import surcharge significantly lowers world prices, which further reduces export profits but also reverses part of the decline in the volume of imports. In addition, lower world prices also increase the value of total imports, because, in the Michigan model, price elasticities of import demand are larger than one in all tradable indus-

\footnotetext{
${ }^{2}$ All estimates of supply and demand elasticities are, admittedly, only best "guesstimates". But Rousslang and Suomela's selection of supply elasticities is open to question. Following Basevi, they use estimates provided by Floyd (1965). Floyd's preferred estimate for the export supply elasticity is 4.5 , and he puts the import supply elasticity at 6.1 . These estimates apply to all industries, and there is no sectoral dissagregation. Presumably, Rousslang and Suomela use these aggregate figures for all industries. In contrast, in the Michigan model, there is considerable variation in supply elasticities across industries with a low of 0.5 in agriculture to a high of 31.1 in the petroleum industry.
} 
tries. In ignoring world price adjustments, Rousslang and Suomela's partial equilibrium approach may overestimate the trade balance improvement caused by the import surcharge.

4. From the previous discussion, it becomes clear that Rousslang and Suomela's analysis does not allow for any negative feedback of tariff changes on exports. Thus, unless intermediate inputs are a very important component of total imports, their results will exaggerate the negative import effects of the surcharge. The trade balance is therefore likely to improve more in their partial equilibrium model, which would lead to a stronger appreciation of the exchange rate.

\section{B. The Effects of a 20 Percent Surcharge on all Imports, with Flexible Exchange Rates}

Turning to the results, the main conclusions are as follows:

1. If the U.S. were to impose a 20 percent surcharge on all imports, this would raise domestic prices of imports and hence lower import demand. The U.S. trade balance would improve and, in this first experiment, there would be an appreciation of the dollar. Our computational results suggest that the dollar would appreciate by 5.2 percent with respect to the yen and 4.7 percent with respect to the Deutsche Mark. The overall trade-weighted effective exchange rate of the dollar would appreciate by 4 percent. The dollar appreciation would make American products more expensive abroad so that exports would fall until trade equilibrium was restored. In Rousslang and Suomela's experiment the dollar appreciates by 14.4 percent, which as expected, is well above the appreciation in the Michigan model, reflecting a larger trade balance improvement.

2. An import surcharge would generate tariff revenues that might help to reduce the U.S. budget deficit. A 20 percent surcharge on all imports would raise the share of government revenues in GDP by an estimated 1 percent, which in 1985 prices would amount to $\$ 38.6$ billion of additional revenues and a 19.1 percent reduction in the current U.S. budget deficit of $\$ 202$ billion. In the Rousslang and Suomela study, the budget deficit improves by $\$ 55.8$ billion.

3. The Michigan model measures the welfare effects of trade policy with standard partial equilibrium welfare estimates, based upon changes in total expenditure plus consumer and producer surplus. 
In the case of a general 20 percent import surcharge, the U.S. would experience a decline in economic welfare of an estimated $\$ 5.5$ billion, which corresponds to a 0.14 percent loss in GDP. This would be a continuing loss in welfare as long as the surcharge remained in effect.

In Table 1, we compare the two studies in terms of the sectoral trade adjustments to an import surcharge. Since Rousslang and Suomela only report the absolute changes in the sectoral trade balance without mentioning the source and year of their trade data, we have calculated the percentage shares of each sector with a trade balance improvement or deterioration in relation to all industries positively or negatively affected by the surcharge. Thus, for example, the result for agriculture in the first column indicates that the trade balance of that sector improved as the result of the surcharge and that its surplus accounted for 7.3 percent of all sectoral trade surpluses. The sectoral trade balance of the food, beverages, and tobacco industry in the same column shows a deficit, amounting to 11.6 percent of the total trade deficit in all negatively affected industries.

As could be predicted, Table 1 indicates that, in the Rousslang and Suomela experiment, fewer industries incur a sectoral trade-balance deficit. Except for agricultural products, all industries with a trade deficit, including food, beverages, tobacco, printing and publishing, chemicals, and nonelectrical machinery, also suffer trade losses in the experiments with the Michigan model. But the Michigan model suggests substantial trade deficits in the textile and leather industries, caused by a significant decline in exports. The absence of intermediate inputs in the partial equilibrium approach may explain this difference in results. Both studies find the most significant trade surpluses in the petroleum, rubber, other manufactured products, and transport industries. These are the sectors with the largest reductions in import demand and the best opportunities for import-competing firms to capture a large share of the domestic market. As far as sectoral trade adjustments are concerned, our results and those of Rousslang and Suomela are fairly similar on the whole, with a correlation coefficient between them of 0.46 . The differences noted stem primarily from the general equilibrium interactions which are captured by the Michigan model.

One of the main drawbacks of Rousslang and Suomela's study is the lack of information about sectoral employment changes. It is true that, up to a point, trade balance and employment adjustments are closely related. A sectoral trade balance surplus, for example, indicates that import demand for the goods of a sector fell more than export 


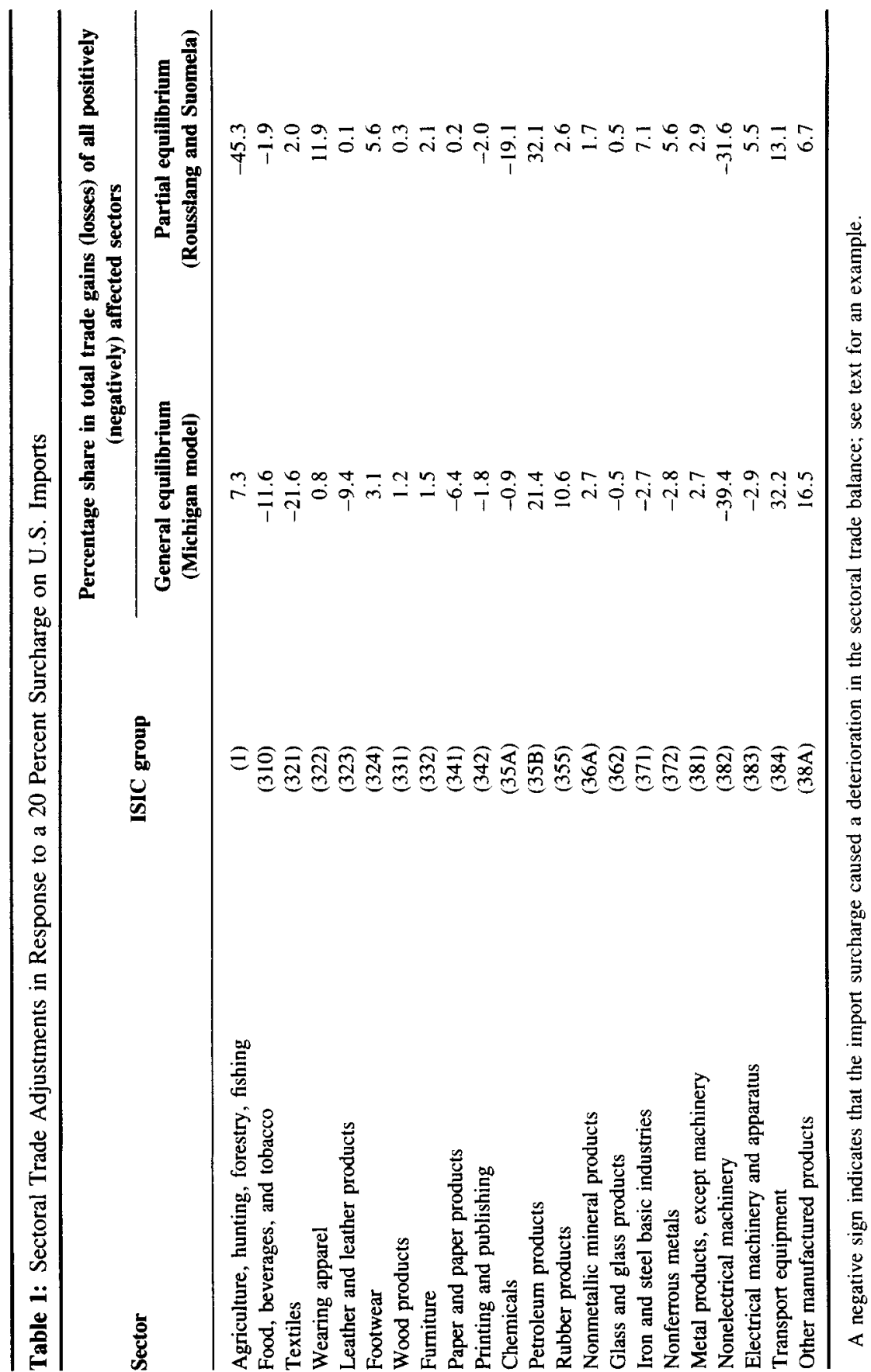


production. This implies that the expansion of import-competing domestic firms exceeds the decline in exports, and we therefore expect total sectoral employment to increase. Yet, there is no doubt that most policymakers are interested in a more quantitative assessment of interindustry employment shifts. For this reason, Table 2 presents percentage and absolute sectoral employment changes in response to a general 20 percent import surcharge. The absolute employment figures in the fourth column are obtained by applying the percentage changes, calculated in the model, to 1985 U.S. employment data.

An important feature of Table 2 is the reallocation of labor from the tradable to the nontradable sectors. A general 20 percent import surcharge would displace 321,001 workers from tradable to nontradable industries. The net employment decline in the tradable sector furthermore implies that, in total, more jobs are lost in export firms than created in import-competing domestic industries. Our calculations thus suggest that an import surcharge may actually result in a decline in U.S. manufacturing employment.

The employment and trade balance changes for the tradable industries contain considerable sectoral variation. The rubber, petroleum, other manufactured goods, and nonmetallic minerals industries would apparently experience a rise in employment as a result of a general 20 percent import surcharge. Yet, except for rubber products, ${ }^{3}$ employment gains are well under 2 percent of industry employment. In most other industries employment would fall in response to a 20 percent import surcharge. The employment declines are especially noteworthy in agricultural and food products, textiles, leather, paper and paper products, chemicals, nonferrous metals, nonelectrical machinery and electrical machinery.

\section{C. A 20 Percent Surcharge on Imports from Japan, Brazil, South Korea, and Taiwan}

As mentioned, some of the current import-surcharge proposals target selected countries with large surpluses in their trade with the U.S. In this section we analyze the impact on the U.S. economy of a 20 percent surcharge on imports from only Japan, South Korea, Taiwan, and

\footnotetext{
${ }^{3}$ The large positive employment effect in the rubber products industry is a result of what we believe to be the unusually large elasticity of demand for imports in that sector. The large negative effect in the leather products industry, on the other hand, may result from an inconsistency in our data on output and trade in that sector, and should be discounted accordingly.
} 
Brazil. As in the first experiment, the exchange rate is assumed to be flexible.

The macroeconomic impact of this policy is comparatively small. The effective exchange rate of the dollar would appreciate by 1 percent, the general price level would increase by 0.2 percent, and welfare losses would be much smaller than in the earlier experiments. The share of government revenues in GDP would rise by an estimated 0.2 percent, which would yield $\$ 8.3$ billion of additional revenues and reduce the (1985) budget deficit by 4 percent.

In the experiments of Rousslang and Suomela, the selective import surcharge is only imposed on imports from Japan. If we conduct the same experiment, we find that the dollar would appreciate by 0.8 percent and the budget deficit would be reduced by $\$ 6$ billion. Rousslang and Suomela find a $\$ 6.3$ billion increase in government revenues and a stronger $2.1 \%$ appreciation of the dollar.

As is seen in Table 3, the sectoral adjustments to an import surcharge against Japan, South Korea, Taiwan, and Brazil are smaller than in the case of a 20 percent surcharge on all imports. Nearly 71,000 workers would be reallocated from tradable to nontradable industries, and the agriculture and food, textile, leather, paper and paper products, chemicals, and nonelectrical machinery sectors again show declines in employment. Small employment gains are now found in such sectors as iron and steel, metal products, and wearing apparel as well as in other manufactured products. These are industries in which Japanese, Brazilian, South Korean, and Taiwanese import penetration is generally the strongest and added tariff protection would therefore provide expansion possibilities for import-competing firms. The sectoral trade and employment adjustments to an import surcharge against Japanese products only are similar and reasonably close to the results of Rousslang and Suomela.

\section{A 20 PERCENT IMPORT SURCHARGE, WITH A FIXED EXCHANGE RATE}

The macroeconomic models of several countries are linked together in a consistent world trade system in Project LINK. Its primary goal is to forecast the path of macroeconomic variables such as GNP, aggregate employment, inflation, and total exports and imports over time. The main orientation of LINK is therefore macroeconomic, and in this light, it has only a limited sectoral disaggregation into four industries. As already noted, the Michigan model is geared towards microeconomic analysis on a disaggregated sectoral level, and its ma- 


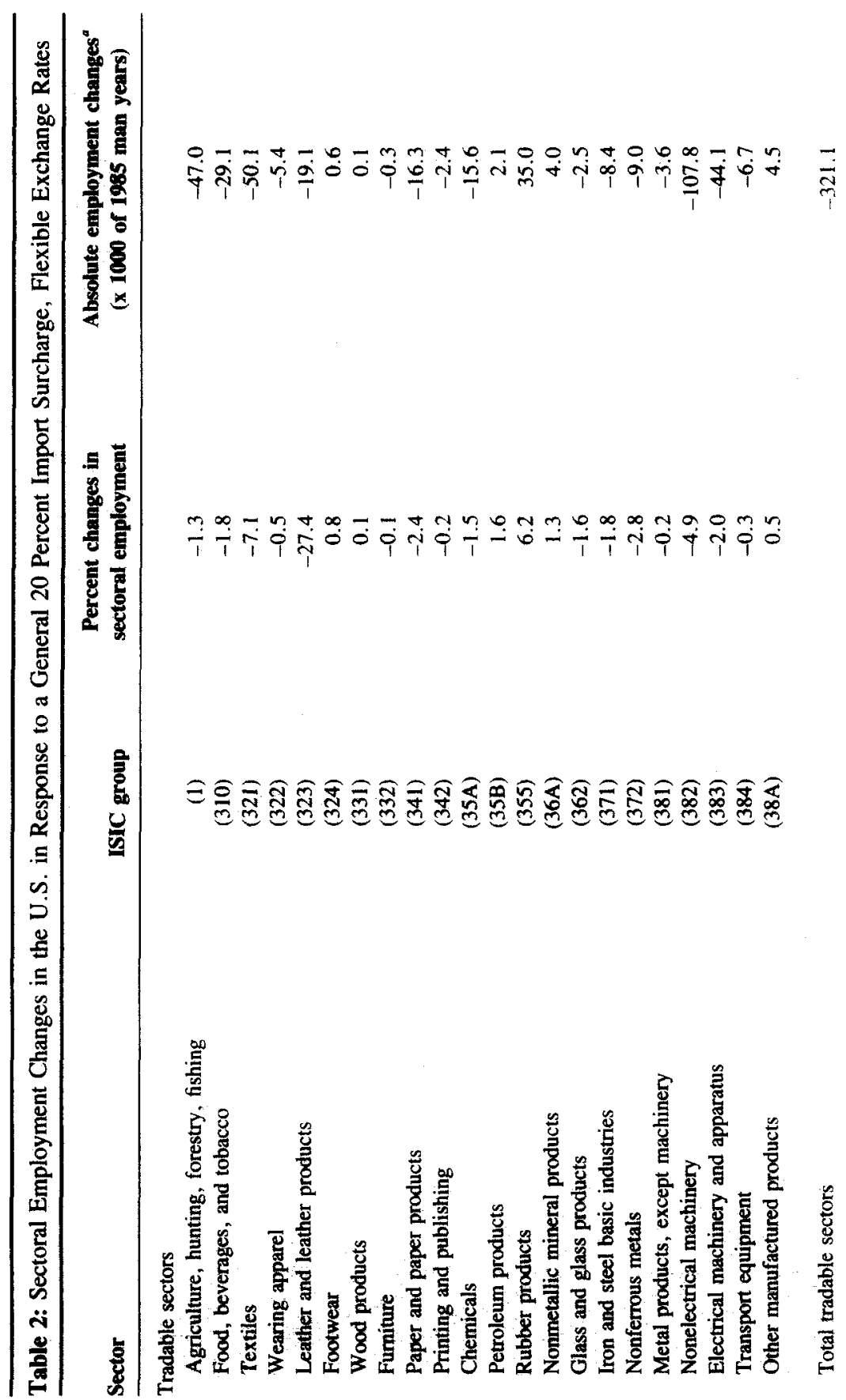


ECONOMIC CONSEQUENCES OF AN IMPORT SURCHARGE

299

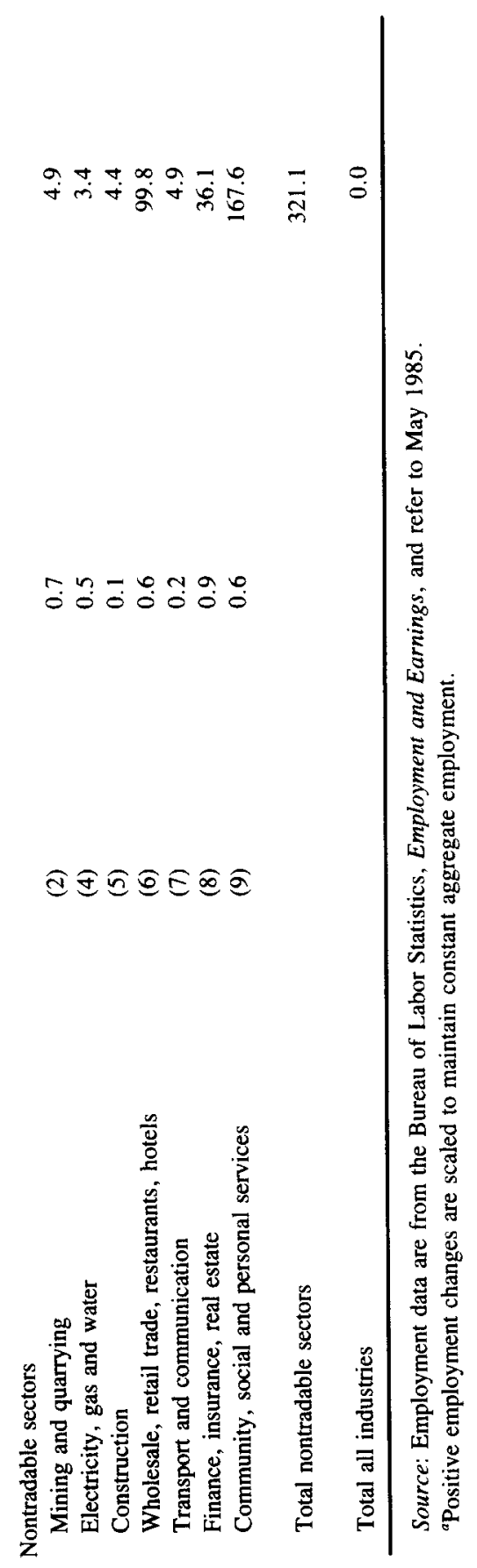




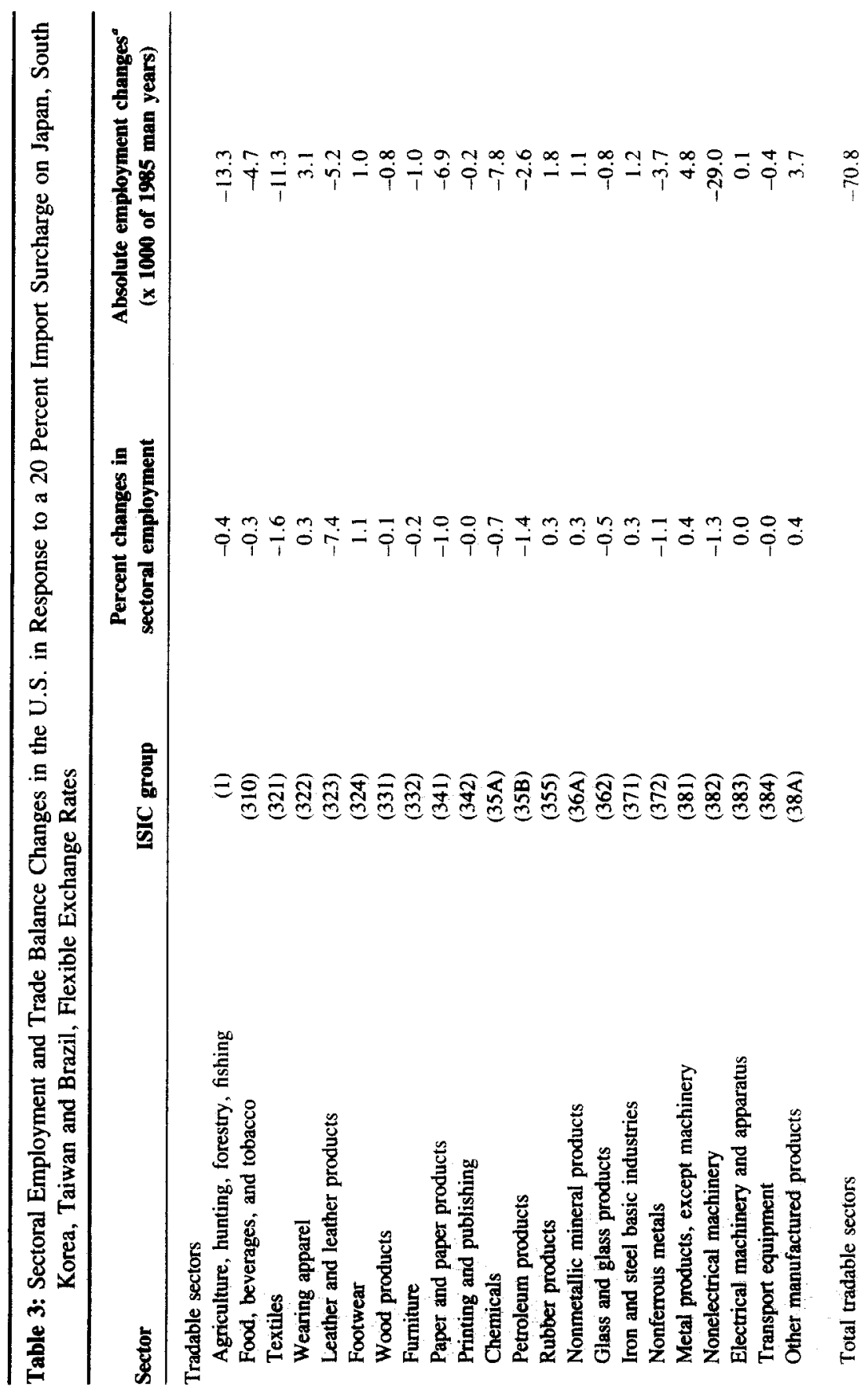




$$
\bar{a}
$$


croeconomic features are kept simple. Adjustments in aggregate expenditure are assumed to maintain full employment. In this way, fluctuations in total employment are deliberately ruled out, in order to focus on intersectoral employment shifts.

The structure of the LINK country models reflects the project's dominant macroeconomic orientation. Although it is impossible to summarize the variety of individual country characteristics, it is safe to say that most models are Keynesian in spirit and based on the identity between GNP and aggregate demand: ${ }^{4}$

$$
\mathrm{GNP}_{i}=E_{i}+X_{i}-M_{i} \text {. }
$$

Demand functions are then estimated for the various components of aggregate demand. Import demand is specified as a function of expenditure and relative prices:

$$
D_{i j}^{m}=D_{i j}^{m}\left(\frac{p_{i j}^{m}}{p_{i j}^{h}}, E_{i}\right)
$$

Except for some countries, intermediate import demand is generally ignored.

The supply side of most country models consists of a set of price equations, which relate output prices to wage rates and costs of imported materials but not to output levels. This implies that, at the prevailing market price, supply is infinitely elastic as would be the case with a constant-returns-to-scale technology. In some countries demand variables are included in the price equations, indicating an imperfectly competitive market structure. At the same time, however, demand functions are estimated, which makes a correct interpretation of the price equation difficult. Ignoring this ambiguity, we write the export price equation as

$$
p_{i j}^{x}=p_{i j}^{x}\left(w_{i j}, P_{i j}^{M}\right)
$$

where

$P_{i j}^{M}=$ price index of imported materials used in industry $j$ of country $i$.

Equation $(2 \mathrm{c})$ is best understood as the inverse of a supply function such as equation (2).

The LINK project seeks to tie the individual country models together in a consistent world trade system. At the heart of the LINK approach are two fundamental world trade identities. A first condition states that, for each good, the quantity exported by one country must be equal to the quantity imported by the country's trading partners:

${ }^{4}$ The description of the LINK model is based on Ball (1973), Klein and Su (1979), and Klein (1985) 


$$
S_{i j}^{\mathrm{x}}=\sum_{\mathbf{k}=1}^{\mathrm{m}} a_{i j k} D_{k j}^{m}
$$

where

$a_{i j k}=\frac{S_{i j k}^{x}}{D_{k j}^{m}}=$ ratio of exports of good $j$ from country $i$ to country $k$ $\left(S_{i j k}^{x}\right)$

to the total imports of country $k$ of product $j\left(D_{k j}^{m}\right)$

The exports of each country are evaluated by equation (12) as a weighted sum of partner country imports. A similar identity must hold in value terms. After adjusting for exchange rates and tariffs, the import value of a good for a country must equal the value of exports supplied by foreign producers. Hence,

$$
p_{k j}^{m} D_{k j}^{m}=\left(1+t_{k j}^{m}\right) \sum_{\mathrm{i}=1}^{\mathrm{m}} p_{i j}^{x} S_{i j k}^{x}
$$

or, substituting from equation (12),

$$
p_{k j}^{m}=\left(1+t_{k j}^{m}\right) \sum_{i=1}^{m} a_{i j k} p_{i j}^{x}
$$

where

$$
t_{k j}^{m}=\text { estimate of average tariff rate on good } j \text { in country } k .
$$

Equation (13) expresses the import price as a weighted average of partner country export prices. Since export prices and import demand are given by equations (2c) and (4c), (12) and (13) can be solved iteratively for the export quantities and import prices, consistent with world trade equilibrium.

An import surcharge not only increases import prices directly in equation (13), but also pushes up output prices of exporting firms [see equation (2c)]. Depending on the magnitude of the export shares, $a_{i j k}$, this indirectly puts additional pressure on import prices, which further reduces import demand. Hence, in LINK, an import surcharge results in higher international goods prices, while world prices fall in the Michigan model because of lower import demand. This different result is explained by LINK's assumptions about the supply function. When export supply is infinitely elastic, export prices are entirely cost determined and not lowered by the decline in import demand. As a result, both the export and import price response to a surcharge are expected to be stronger in the LINK surcharge experiments. The final adjustment 
of import demand is more difficult to predict because the import losses in the LINK model, due to rising world prices, may be dominated by the reduction in intermediate imports in the Michigan model.

The impact of the surcharge on the volume of exports also differs in the LINK and Michigan models. Equation (12) defines exports in LINK as a weighted average of partner country import demands. The weights $a_{i j k}$ are not directly influenced by the tariff policy so that the competitive position of export firms in the country with the surcharge does not deteriorate vis-à-vis foreign exporters. The direct relation involving the surcharge, the cost of intermediate inputs, and export supply is missing from the LINK model. As a result, exports in the country with the surcharge only go down in proportion to the general decline in world import demand. For this reason, a surcharge leads to a stronger contraction in the export sector of the Michigan than of the LINK model.

Because of the ambiguous results for import demand, it is not possible to say whether the trade balance will improve more in the LINK than in the Michigan model experiments. In any event, the trade balance surplus does not cause an appreciation because exchange rates are exogenously given. This exogeneity assumption implies that, although the LINK model contains a monetary sector, the interaction between the money and foreign exchange markets is not modeled explicitly.

\section{A. The Effects of A 20 Percent General Import Surcharge, with a Fixed Exchange Rate}

In the experiment discussed in this section, the import surcharge leaves the exchange rate unchanged. By reducing the budget deficit, the surcharge lowers the real interest rate, which reduces international capital flows to the U.S. and offsets any positive trade balance effects on the exchange rate. The same assumption about the exchange rate is made in the LINK simulations, but the design of the experiments is somewhat different. Klein et al. (1985) consider the one- and fiveyear effects of a three-year sliding surcharge from 1986 to 1988 , with rates of 20 percent, 15 percent, and 7 percent, respectively. To allow a comparison with the results of the Michigan model, we focus on the first-year adjustments to the 20 percent surcharge. The major results are as follows:

1. As expected, export and import prices react more strongly to the import surcharge in the LINK model than in the Michigan model. The U.S. import-goods price deflator in the LINK model shows 
a 20.2 percent increase, while the LINK estimate for the U.S. export-goods deflator increases by 2.6 percent. In the Michigan model, import prices go up by an average of 16.4 percent, while export prices fall by 0.8 percent due to lower world prices.

2 . In sharp contrast to the 10.1 percent export decline in the Michigan model, export production is virtually unchanged in the LINK experiment. Import demand falls substantially more in the Michigan ( -22.7 percent) than in the LINK model ( -4.2 percent). This may be the consequence of intermediate input demand, but may also reflect slow adjustment of imports over time. That is, much of the change of imports in LINK takes place in the second and third year and the combined import reduction after five years of the three-year sliding surcharge is 14.9 percent.

3 . The LINK study provides a wide range of macroeconomic estimates. The LINK results suggest that the surcharge would cause a small reduction in GNP of 0.2 percent, which would lead to 0.2 percent more unemployment in the United States. Interest rates would fall and the consumer price index would increase by about 0.6 percent. The federal deficit would be reduced by $\$ 59.8$ billion, compared to only $\$ 37.4$ billion in the Michigan model.

4. Because of the limited sectoral disaggregation of the LINK model, the Michigan model provides more detailed information about sectoral employment shifts. Table 4 shows that, if the value of the dollar remains unchanged when the surcharge is imposed, there is an employment shift from the nontradable to the tradable sectors. Export production will fall because of more expensive imported inputs, but the decline is less pronounced now as compared to the previous experiments since the dollar does not appreciate. As a result, more tradable sectors experience a net employment gain than in the first experiment. Total employment in tradable industries increases by approximately 180,000 man years. Obviously, the sectors which gained in the previous experiment would continue to do so, but, in addition, agricultural and food products, transport equipment, metal products, and chemical industries expand. Textiles, leather, and nonelectrical machinery are among the major victims of the surcharge in this second experiment.

\section{CONCLUSION}

An import surcharge might help to resolve some current economic problems, but aggravate others. A 20 percent surcharge on all imports 


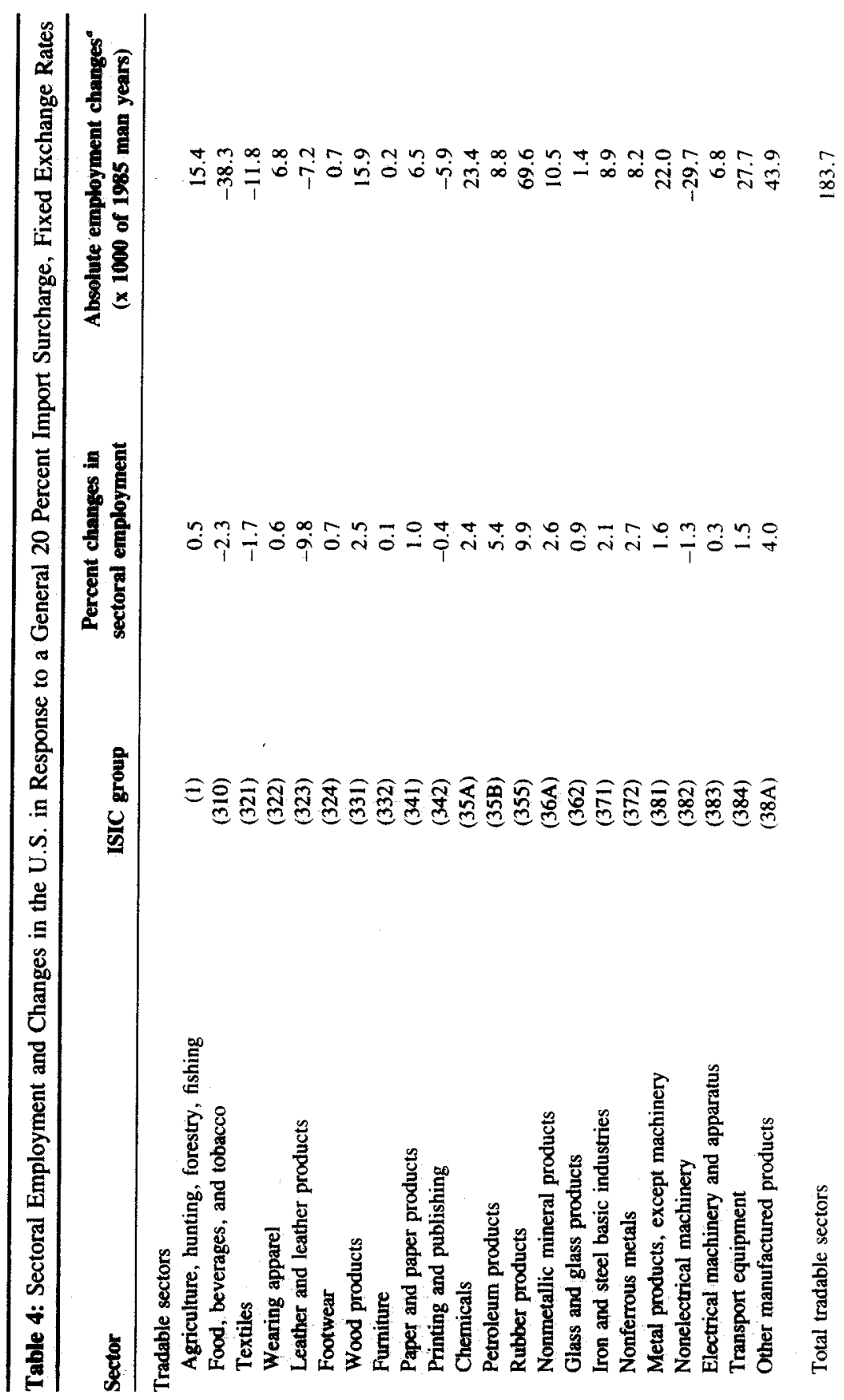




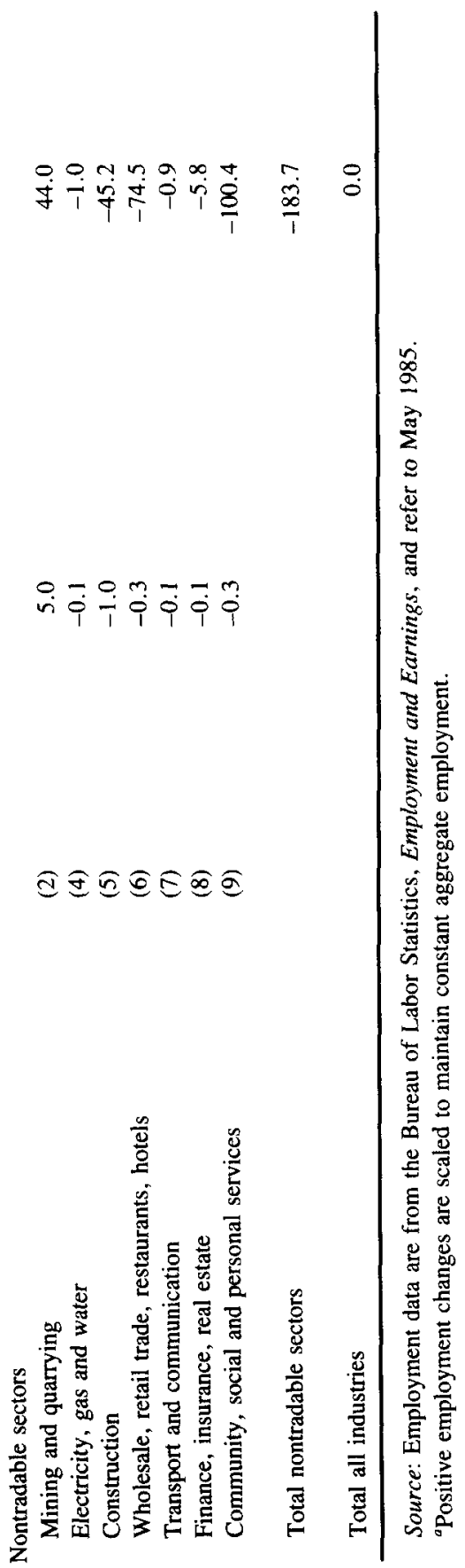


would help to reduce the government deficit, lower imports, and stimulate production for the domestic market. On the other hand, the general price level would rise, economic welfare would go down, and jobs would be lost in the export sector. In the aggregate, employment and production effects would be limited.

A major goal of an import surcharge is to strengthen the competitive position of U.S. industries. But, as our computations suggest, this goal is only attained if the dollar does not appreciate in response to an import surcharge, because an appreciation substantially reduces U.S. export strength, which might reduce total employment in several important U.S. tradable industries. In case a surcharge were directed only at countries with large surpluses in their trade with the U.S., the results suggest comparatively small effects in the aggregate but some intersectoral employment adjustments are likely to occur.

In the alternative scenario in which the exchange rate is assumed to remain unchanged with the imposition of a surcharge, the employment effects are positive for most but not all tradable industries. The plausibility of these two exchange-rate scenarios clearly depends on which macroeconomic effects are believed to be the most realistic. Considering the small aggregate adjustments, the experiments that assume flexible exchange rates appear to us the most credible.

Reviewing the partial equilibrium effort by Rousslang and Suomela, we noted that their approach left out the role of intermediate inputs and did not capture the repercussions of world trade adjustments on the U.S. domestic economy and the rest of the world. Accordingly, one should view their estimates of an import surcharge with some skepticism. As for the Michigan and Project LINK approaches, it appears that LINK's macroeconomic orientation and limited sectoral disaggregation make it more suited for analyzing the macroeconomic aspects of a U.S. import surcharge. The Michigan model explicitly abstracts from macroeconomic interactions and offers instead a more detailed insight into the sectoral trade and employment adjustments that would be associated with an import surcharge.

\section{REFERENCES}

Ball, R. J. (1973) The Economic Models of Project LINK, in The International Linkage of National Economic Models, (R.J. Ball ed.). Amsterdam: North-Holland.

Basevi, G. (1968) The Restrictive Effects of the U.S. Tariff and its Welfare Value. American Economic Review 58: 840-852.

Brown, D. K. (1984) The Economic Effects of the Tokyo Round, Using a Computational Model with Bilateral Trade Flows, and Commercial Policies. Ph.D. Dissertation, The University of Michigan.

Deardorff, A. V., and Stem, R. M. (1986) The Michigan Model of World Production and Trade: Theory and Applications. Cambridge: MrT Press. 
Floyd, J.E. (1965) The Overvaluation of the Dollar. American Economic Review, 55:95-107. Klein, L. R. (1985) Empirical Aspects of Protectionism. Journal of Policy Modeling 7:35-47.

Klein, L. R. and Su, V. (1979) Protectionism: An Analysis from Project LINK. Journal of Policy Modeling 1:5-35.

Klein, L. R., Pauly, P. and Petersen, C. E. (1985) Import Surcharges, U.S. Deficits, and the World Economy, Project LINK Working Paper, April 1985.

Rousslang, D. J., and Suomela, J. W. (1985) Trade Effects of a U.S. Import Surcharge. Journal of World Trade Law 19:441-451. 